\title{
Analisis Prediksi Path Loss Teknologi Seluler 5G Pada Sel Micro Urban Wilayah Kota Bandung
}

\author{
DWI ARYANTA
}

Institut Teknologi Nasional Bandung

Email : dwiaryanta@itenas.ac.id

Received 15 Februari 2021 | Revised 16 Maret 2021 | Accepted 21 Maret 2021

\begin{abstract}
ABSTRAK
Implementasi teknologi seluler $5 G$ di Indonesia perlu dilakukan kajian dalam beberapa aspek. Analisis nilai path loss pada sistem seluler merupakan pendekatan dalam aspek large scale fading untuk menghitung cakupan layanan. Penelitian ini melakukan kajian nilai path loss dengan mengambil kondisi di Kota Bandung dengan karakter sel urban mikro outdoor. Model prediksi yang digunakan pada kajian ini meliputi model SUI, ABG, CI, dan NYUSIM simulator menggunakan frekuensi kerja 3,5 GHz dan $28 \mathrm{GHz}$ dengan lebar pita $100 \mathrm{MHz}$ dan $800 \mathrm{MHz}$. Hasil pengujian memperlihatkan simulator NYUSIM memberikan nilai prediksi path loss yang paling mendekati nilai rata-rata path loss dengan nilai margin sebesar 1,25 $d B$ untuk frekuensi 3,5 GHz dan 1,8 dB untuk frekuensi $28 \mathrm{GHz}$. Frekuensi kerja 28 $\mathrm{GHz}$ memiliki nilai path loss lebih tinggi dibandingkan frekuensi 3,5 MHz sebesar 19 dB. Nilai path loss pada kondisi LOS dan NLOS berdampak pada penurunan nilai path loss sebesar $35 \%$ pada frekuensi $3,5 \mathrm{GHz}$ dan $26 \%$ pada frekuensi $28 \mathrm{GHz}$.
\end{abstract}

Kata kunci: path loss, micro cell, urban, NYUSIM, LOS, NLOS

\begin{abstract}
The implementation of $5 G$ cellular technology in Indonesia needs to be studied in several aspects. Analysis of the path loss value on the cellular system is an approach in the aspect of large scale fading to calculate service coverage. This research studies the path loss value by taking conditions in the city of Bandung with the character of outdoor micro urban cells. The prediction models used in this study include the SUI, ABG, CI, and NYUSIM simulators using working frequencies of $3.5 \mathrm{GHz}$ and $28 \mathrm{GHz}$ with a bandwidth of $100 \mathrm{MHz}$ and $800 \mathrm{MHz}$. The test results show that the NYUSIM simulator provides a path loss prediction value that is closest to the average path loss value with a margin value of $1.25 \mathrm{~dB}$ for the $3.5 \mathrm{GHz}$ frequency and $1.8 \mathrm{~dB}$ for the $28 \mathrm{GHz}$ frequency. The $28 \mathrm{GHz}$ working frequency has a path loss value higher than the 3.5 MHz frequency of $19 \mathrm{~dB}$. The path loss value in $\angle O S$ and NLOS conditions has an impact on reducing the path loss value by $35 \%$ at a frequency of $3.5 \mathrm{GHz}$ and $26 \%$ at a frequency of $28 \mathrm{GHz}$.
\end{abstract}

Keywords: path loss, micro cell, urban, NYUSIM, LOS, NLOS 


\section{PENDAHULUAN}

Teknologi seluler selalu berevolusi dari tahun ke tahun, dimana saat ini sudah memasuki generasi $5 \mathrm{G}$ dengan indikator peningkatan yang siginifikan pada kecepatan, cakupan, dan kehandalan. Konsekuensi dari teknologi $5 \mathrm{G}$ ini menuntut solusi perubahan jaringan baik dalam bentuk pengembangan jaringan eksisting maupun potensi implementasi jaringan baru, model distribusi yang baru termasuk dimensi sel yang kecil, infrastruktur jaringan yang sesuai yang dapat meliputi interkoneksi antara jaringan wireless dan serat optik, serta akses ke spektrum frekuensi yang berbeda (Ofcom, 2017).

Teknologi 5G New Radio(NR) membutuhkan tiga lingkup spektrum frekuensi yaitu Low bands, Mid bands dan High bands. Spektrum Low bands di bawah $1 \mathrm{GHz}$ diperlukan untuk penanganan dalam hal coverage terutama untuk aplikasi MMTC (massive IoT dan mobile broadband). Spektrum Mid bands pada frekuensi 1 hingga $6 \mathrm{GHz}$ dengan bandwidth yang lebih lebar diperlukan pada layanan Enhanced Mobile Broadband (eMBB) dan mission-critical, sedangkan spektrum High bands pada frekuensi di atas $24 \mathrm{GHz}$ (mm Wave) digunakan untuk memberikan layanan troughput yang sangat besar (Puslitbang SDPPI, 2018).

Gelombang milimeter ( $\mathrm{mm}$ Wave) merupakan frekuensi yang memiliki panjang gelombang 10 hingga 1 milimeter. Gelombang milimeter menduduki pita frekuensi 30 - $300 \mathrm{Ghz}$ dikenal sebagai Extremely High Frequency (EHF). Frekuensi gelombang milimeter yang tinggi serta karakteristik propagasi yang khusus memiliki keuntungan untuk dipakai pada berbagai aplikasi termasuk transmisi data berkecepatan tinggi pada jaringan wireless, dan seluler. Penggunaan kanal bandwidth yang lebih besar: $2 \mathrm{GHz}, 4 \mathrm{GHz}, 10 \mathrm{GHz}$ bahkan $100 \mathrm{GHz}$ mampu menyediakan kecepatan yang setara dengan penggunaan fiber optik (Rappaport, dkk, 2013).

Pada kajian whitepaper yang dilakukan oleh 5G Americas terkait dengan rekomendasi spektrum untuk teknologi 5G, dalam whitepaper tersebut dijelaskan bahwa rentang frekuensi yang sesuai untuk 5G akan mencakup pita-pita di bawah $6 \mathrm{GHz}$ seperti spektrum 2G / 3G hasil re-farming, pita frekuensi yang teridentifikasi untuk IMT dan juga band-band WRC-15. Namun, karena kelangkaan spektrum di bawah $6 \mathrm{GHz}$, yang hampir sepenuhnya digunakan dan akan lebih sulit untuk menemukan spektrum harmonis internasional setelah WRC-15, perlu mencari rentang frekuensi potensial di atas $6 \mathrm{GHz}$. Pembagian spektrum terkontrol merupakan cara penting untuk menggunakan kembali spektrum untuk melengkapi spektrum khusus berlisensi saat ini, yang masih menjadi dasar untuk pengoperasian sistem 5G (5G Americas, 2017).

Secara teoritis penggunaan frekuensi yang semakin tinggi akan memperkecil cakupan layanan seluler karena redaman lintasan (path loss) yang terjadi semakin membesar untuk jarang pengukuran yang sama. Dampak positif dari penggunaan frekuensi dan bandwidth yang tinggi adalah besarnya kapasitas transmisi data yang mampu diberikan. Terdapat sejumlah model prediksi perhitungan path loss untuk membantu perencanaan perhitungan coverage sel yang mendasari proses desain jaringan suatu sistem seluler.

Pemodelan kanal menjelaskan bagaimana parameter saluran nirkabel berperilaku dalam skenario tertentu, dan membantu mengevaluasi kinerja link dan sistem. Model saluran harus dapat memberikan parameter saluran yang diperoleh dalam pengukuran lapangan dan secara akurat memprediksi respons impuls saluran pada large scale fading. Kajian mengenai pembandingan dua model saluran populer untuk komunikasi generasi $5 \mathrm{G}$ yaitu model prediksi yang dikeluarkan olah 3GPP dan model saluran spasial statistik NYUSIM dikembangkan oleh New York University (NYU). Kedua model saluran menggunakan pendekatan pemodelan yang berbeda dalam banyak aspek, seperti probabilitas line-of-sight, path loss, dan metodologi clustering. Simulasi dilakukan dengan menggunakan model dua saluran untuk menganalisis 
distribusi nilai eigen saluran dan efisiensi spektral yang memanfaatkan metode pembentukan berkas hibrid analog/digital yang ditemukan dalam literatur. Hasil simulasi menunjukkan bahwa model 3GPP menghasilkan nilai eigen yang berbeda dan distribusi efisiensi spektral untuk pita mm Wave, dibandingkan dengan hasil dari NYUSIM yang didasarkan pada sejumlah besar data pengukuran dunia nyata di New York City. Karya ini menunjukkan NYUSIM lebih akurat untuk simulasi realistis daripada 3GPP di lingkungan perkotaan (Rappaport, dkk, 2017).

Suatu penelitian dilakukan untuk membandingkan dua kandidat model prediksi path loss propagasi large scale fading, model Alpha-Beta-Gamma (ABG) dan model jarak referensi ruang bebas Close-In (CI), untuk desain komunikasi nirkabel generasi kelima (5G). Sistem menerapkan skenario mikro dan makro seluler di wilayah perkotaan. Perbandingan dibuat menggunakan data yang diperoleh dari 20 hasil pengukuran propagasi atau studi ray-tracing pada frekuensi $2 \mathrm{GHz}$ hingga $73,5 \mathrm{GHz}$ dengan jarak mulai dari $5 \mathrm{~m}$ hingga $1429 \mathrm{~m}$. Hasilnya menunjukkan bahwa model CI memiliki satu nilai parameter yang sesuai pada lingkungan lineof-sight (LOS) maupun non-line-of-sight(NLOS). Model CI lebih baik dibandingkan model ABG dalam hal jumlah parameter yang lebih sederhana dan lebih stabil pada variasi frekuensi dan jarak (Sun, dkk, 2016).

Kajian penggunaan simulator NYUSIM digunakan untuk menghasilkan respons saluran spasial dan temporal yang realistis untuk mendukung simulasi dan desain lapisan fisik dan tautan yang realistis untuk komunikasi seluler generasi kelima (5G). NYUSIM dibangun di atas model saluran spasial statistik untuk sistem komunikasi nirkabel gelombang milimeter-gelombang (mm Wave) yang dikembangkan oleh para peneliti di Universitas New York (NYU). Simulator berlaku untuk berbagai frekuensi pembawa ( $500 \mathrm{MHz}$ hingga $100 \mathrm{GHz}$ ), bandwidth frekuensi radio (RF) (0 hingga $800 \mathrm{MHz}$ ), lebar berkas antena (7० hingga 360 untuk azimuth dan $7^{\circ}$ hingga $45^{\circ}$ untuk ketinggian), dan pengoperasian skenario (mikrosel perkotaan, sel makro perkotaan, dan sel makro pedesaan), dan juga menggabungkan susunan antena Multi-Input Multi-Output (MIMO) pada pemancar dan penerima (Sun, dkk, 2017).

Untuk memodelkan path loss berlebih akibat penetrasi ke dalam gedung, model parabola untuk kehilangan penetrasi outdoor ke indoor (O2I) telah diadopsi dari kelompok minat khusus pemodelan saluran 5G dan diimplementasikan di NYUSIM 2.0. Kemampuan pemodelan baru ini mampu mereproduksi data yang realistis ketika diterapkan dalam mode Monte Carlo menggunakan NYUSIM 2.0, menjadikannya simulator saluran berbasis pengukuran yang berharga untuk desain dan evaluasi sistem komunikasi mm Wave generasi $5 \mathrm{G}$ dan generasi berikutnya (Ju, dkk, 2019).

Pengujian Teknologi 5G di Indonesia mengacu pada Keputusan Dirjen 235 Tahun 2018 Tentang Penetapan Pita Frekuensi Radio untuk Uji Coba Penggunaan Teknologi IMT-2020. Pada Keputusan itu menetapkan sejumlah band frekuensi yang dapat digunakan untuk melakukan pegujian teknologi $5 \mathrm{G}$ di Indonesia yaitu pada band 3,5 GHz, band $15 \mathrm{GHz}$, band $26 \mathrm{GHz}$, dan pada band $28 \mathrm{GHz}$. Pertimbangan penetapan band frekuensi untuk pengujian tersebut mengacu pada ekosistem uji coba band frekuensi global dan vendor penyedia perangkat jaringan seluler hanya menyediakan perangkat ujicoba pada rentang band frekuensi tertentu.

Makalah ini menyajikan suatu hasil perhitungan path loss teknologi seluler generasi $5 \mathrm{G}$ dengan kasus studi Kota Bandung dan klasifikasi cakupan sel micro dengan radius coverage hingga 200 meter. Spektrum frekuensi yang digunakan pada penelitian ini adalah pada band 3,5 GHz dan $28 \mathrm{GHz}$, masing-masing dengan lebar pita $100 \mathrm{MHz}$ dan $800 \mathrm{MHz}$. Model prediksi yang digunakan untuk melakukan perhitungan path loss antara lain model NYUSIM, ABG, CI, dan Stanford University Interim (SUI). Analisis dilakukan pada semua hasil perhitungan path loss dari masing-masing model yang digunakan, dan dapat diputuskan model prediksi perhitungan

$$
\text { ELKOMIKA - } 550
$$


path loss yang optimum untuk digunakan dalam perencanaan jaringan teknologi $5 \mathrm{G}$. Penggunaan model prediksi path loss yang optimal menjadi acuan dalam hal perhitungan link budget dan kemudian digunakan untuk melakukan perancangan cakupan layanan teknologi seluler 5G pada suatu kondisi tertentu sebelum melakukan implementasi.

\section{METODE PENELITIAN}

\subsection{Model Prediksi Redaman Propagasi}

Pada perencanaan jaringan seluler untuk memodelkan cakupan suatu base station perlu diketahui nilai redaman lintasan sehingga pemilihan jenis perangkat yang diperlukan dapat menjadi optimal. Terdapat sejumlah model prediksi path loss yang dapat digunakan untuk perencanaan jaringan yang mendukung implementasi teknologi seluler 5G. Penggunaan beberapa model prediksi path loss diperlukan untuk mencari nilai optimal redaman lintasan untuk mengurangi faktor kesalahan perencanaan. Model ABG, CI, dan SUI adalah model yang menggunakan persamaan untuk menghitung prediksi path loss, sedangkan NYUSIM merupakan suatu software dengan sejumlah pengaturan parameter sesuai kebutuhan.

\subsubsection{Model Prediksi ABG}

Model prediksi path loss ABG dikeluarkan oleh The Third Generation Partnership Project (3GPP) yang merupakan suatu kelompok proyek yang mengembangkan teknologi seluler generasi ketiga. Pada model ini terdapat tiga parameter yang didefinisikan sesuai dengan karakteristik sel dan geotype suatu wilayah. Redaman pada kondisi free space loss merupakan fungsi frekuensi dan jarak yang dinyatakan melalui Persamaan (1) (Sun, dkk, 2016) (Thomas, dkk, 2016).

$$
P L^{A B G}(f, d)=10 \alpha \log \left(\frac{d}{1 m}\right)+\beta+10 \gamma \log \left(\frac{f}{1 G H z}\right)+X_{\sigma}^{A B G}[d B]
$$

Nilai $\alpha$ dan $\gamma$ menyatakan parameter path loss yang terkait dengan jarak dan frekuensi, sedangkan $\beta$ menyatakan nilai offset yang dioptimalkan untuk path loss dalam $\mathrm{dB}$. Nilai frekuensi pada persamaan di atas dinyatakan dalam $\mathrm{GHz}$ dan jarak dalam meter, $X_{\sigma}^{A B G}$ merupakan standar deviasi nilai shadowing fading yang menggambarkan nilai rata-rata path loss sepanjang lintasan akibat fluktuasi large scale fading. Nilai parameter $\alpha, \gamma$, dan $\beta$ untuk berbagai geotype, ukuran sel dan karakteristik propagasi sinyal ditampilkan pada Tabel 1.

\subsubsection{Model Prediksi Path loss Close-In (CI)}

Model prediksi CI mengembangkan model path loss pada ruang hampa dengan memperhitungkan jarak awal 1 meter. Seperti halnya model prediksi ABG, model CI juga merupakan fungsi frekuensi dan jarak yang dinyatakan dengan persamaan (2) (Sun, dkk, 2016).

$$
P L^{C I}(f, d)=20 \log \left(\frac{4 \pi f}{c}\right)+10 \alpha \log (d)++X_{\sigma}^{C I}[d B]
$$

dimana $f$ menyatakan frekuensi yang digunakan pada sistem, $d$ adalah jarak antara pemancar dengan penerima, a menyatakan nilai slope path loss mulai jarak 1 meter dan $X_{\sigma}^{C I}$ adalah variabel acak gaussian dengan mean bernilai nol dengan standar deviasi dalam dB (Haneda, dkk, 2016). Nilai Path loss Exponent (PLE) atau $\alpha$, dan nilai standar deviasi pada model prediksi CI ini dapat dilihat pada pada Tabel 1. 
Tabel 1. Parameter pada Model Prediksi ABG dan CI (S. Sun, 2016)

\begin{tabular}{|c|c|c|c|c|c|c|c|c|}
\hline \multicolumn{2}{|c|}{ Skenario } & $\begin{array}{c}\text { Rentang } \\
\text { Frekuensi (GHz) }\end{array}$ & $\begin{array}{c}\text { Jarak } \\
(\mathbf{m})\end{array}$ & Model & PLE $/ \alpha$ & $\begin{array}{c}\beta \\
(\mathrm{dB})\end{array}$ & $\gamma$ & $\begin{array}{c}\sigma \\
\text { (dB) }\end{array}$ \\
\hline \multirow{4}{*}{$\begin{array}{c}\text { Urban } \\
\text { Micro SC }\end{array}$} & \multirow{2}{*}{ LOS } & \multirow{2}{*}{$2-73,5$} & \multirow{2}{*}{$5-121$} & ABG & 2 & 31,4 & 2,1 & 2,9 \\
\hline & & & & $\mathrm{CI}$ & 2 & - & - & 2,9 \\
\hline & \multirow{2}{*}{ NLOS } & \multirow{2}{*}{$2-73,5$} & \multirow{2}{*}{$19-272$} & ABG & 3,5 & 24,4 & 1,9 & 8 \\
\hline & & & & CI & 3,1 & - & - & 8,1 \\
\hline \multirow{4}{*}{$\begin{array}{l}\text { Urban } \\
\text { Micro OS }\end{array}$} & \multirow{2}{*}{ LOS } & \multirow{2}{*}{$2-60$} & \multirow{2}{*}{$5-88$} & $A B G$ & 2,6 & 24 & 1,6 & 4 \\
\hline & & & & $\mathrm{CI}$ & 1,9 & - & - & 4,7 \\
\hline & \multirow{2}{*}{ NLOS } & \multirow{2}{*}{$2-60$} & \multirow{2}{*}{$8-235$} & ABG & 4,4 & 24 & 1,9 & 7,8 \\
\hline & & & & $\mathrm{CI}$ & 2,8 & - & - & 8,3 \\
\hline \multirow{4}{*}{$\begin{array}{l}\text { Urban } \\
\text { Macro }\end{array}$} & \multirow{2}{*}{ LOS } & \multirow{2}{*}{$2-73,5$} & \multirow{2}{*}{$58-930$} & ABG & 2,8 & 11,4 & 2,3 & 4,1 \\
\hline & & & & $\mathrm{CI}$ & 2 & - & - & 4,6 \\
\hline & \multirow{2}{*}{ NLOS } & \multirow{2}{*}{$2-73,5$} & \multirow{2}{*}{$45-1429$} & $A B G$ & 3,3 & 17,6 & 2 & 9,9 \\
\hline & & & & CI & 2,7 & - & - & 10 \\
\hline
\end{tabular}

\subsubsection{Model Prediksi Path loss SUI}

Model prediksi SUI pada awalnya digunakan pada perhitungan path loss generasi awal teknologi seluler hingga generasi ketiga, yaitu pada frekuensi kerja hingga $2 \mathrm{GHz}$. Formula SUI kemudian dikembangkan sehingga dapat dipergunakan untuk perhitungan prediksi path loss dengan frekuensi kerja $f(\mathrm{~Hz})$ pada jarak $d(\mathrm{~m})$ tertentu pada teknologi $5 \mathrm{G}$ yang dinyatakan dengan persamaan (3) (Sulyman, dkk, 2014).

$$
P L_{S U I}=20 \log \left(\frac{4 \pi f}{c}\right)+10 n \log (d)+X_{f c}+X_{R X}+X_{\sigma} \quad[d B]
$$

Dimana:

$n$ adalah koefisien fungsi jarak $=4,6-0,0075 h_{T X}+\frac{12,6}{h_{T X}}$

$h_{T x}$ adalah tinggi antena base station $(\mathrm{m})$

$h_{R x}$ adalah tinggi user equipment $(\mathrm{m})$

$X_{f C}$ adalah faktor koreksi frekuensi $=6 \log \left(\frac{f_{M H z}}{2000}\right), f_{C}>2 G H z$

$X_{R X}$ adalah faktor koreksi tinggi user equipment $=-10,8 \log \left(\frac{h_{R X}}{2}\right)$

$X_{\sigma}$ adalah variabel log normal random shadowing

\subsubsection{Model Prediksi Path loss Simulator NYUSIM}

Simulator NYUSIM merupakan karya dari New York University yang merupakan suatu aplikasi open source yang digunakan untuk pengukuran saluran propagasi pita lebar dunia nyata yang ekstensif pada beberapa frekuensi gelombang milimeter ( $\mathrm{mm}$ Wave) dari 28 hingga $73 \mathrm{GHz}$ di berbagai lingkungan luar ruangan di lingkungan mikro sel perkotaan (UMi), makro sel perkotaan (UMa), dan makro sel pedesaan (RMa). NYUSIM memberikan perhitungan yang akurat dari respons impuls saluran aktual dalam ruang dan waktu, dan berlaku untuk berbagai frekuensi pembawa mulai $500 \mathrm{MHz}$ hingga $100 \mathrm{GHz}$, dan bandwidth RF dari 0 hingga $800 \mathrm{MHz}$ (Sun, dkk, 2017).

Parameter yang digunakan pada model prediksi NYUSIM jauh lebih kompleks dibandingkan ketiga model prediksi path loss yang telah dibahas sebelumya. Selain frekuensi, jarak, ketinggian antena base station dan ketinggian user equipment, parameter teknis jumlah antena MIMO, serta sudut kemiringan antena juga memperhitungkan skenario wilayah (urban mikro/UMi, urban makro/UMa dan rural makro/RMa) juga mempertimbangkan kondisi LOS dan NLOS. Parameter kondisi cuaca juga diperhitungkan seperti temperatur udara, 
kelembaban dan curah hujan (Ju, dkk, 2020). Selengkapnya tampilan menu utama pada simulator NYUSIM ditampilkan pada Gambar 1.

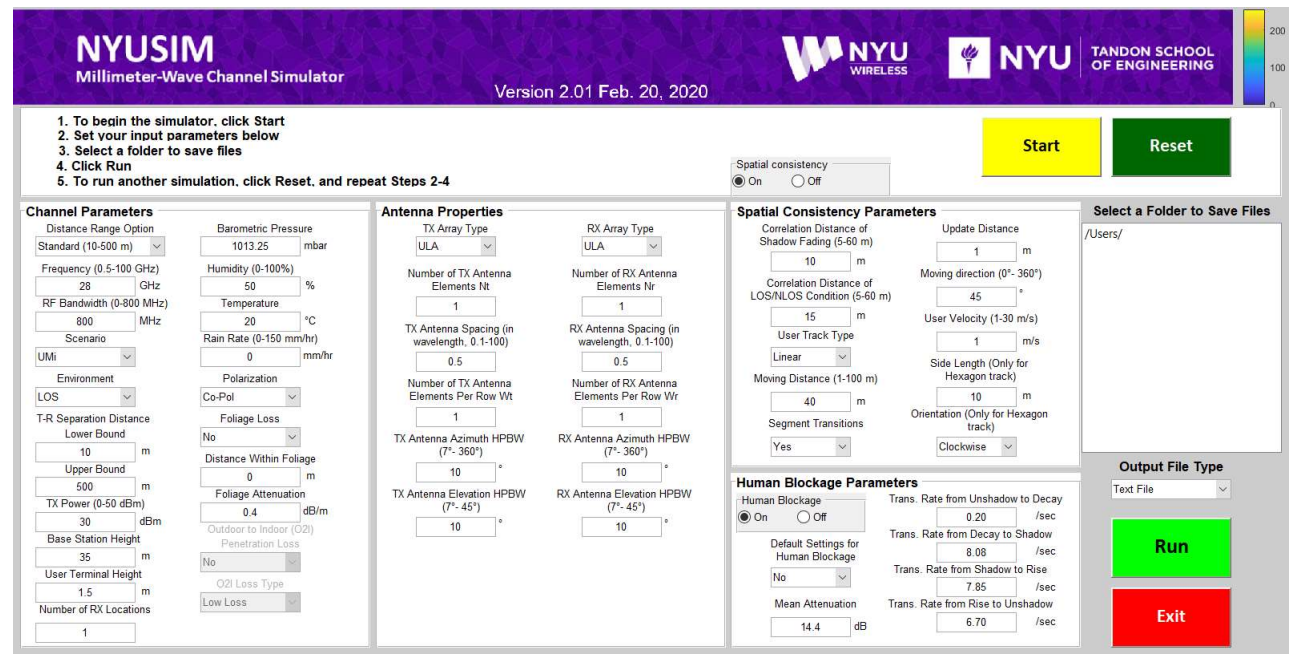

Gambar 1. Tampilan Menu Utama Simulator NYUSIM

\subsection{Teknologi Seluler 5G}

Perkembangan teknologi seluler saat ini sudah memasuki generasi 5, dimana sudah cukup banyak negara lain yang telah menerapkan teknologi seluler 5G ini. Teknologi seluler 5G memiliki sejumlah target parameter layanan dan kinerja sistem seperti yang dapat dilihat pada Gambar 2 berikut (Obiodu, 2019).

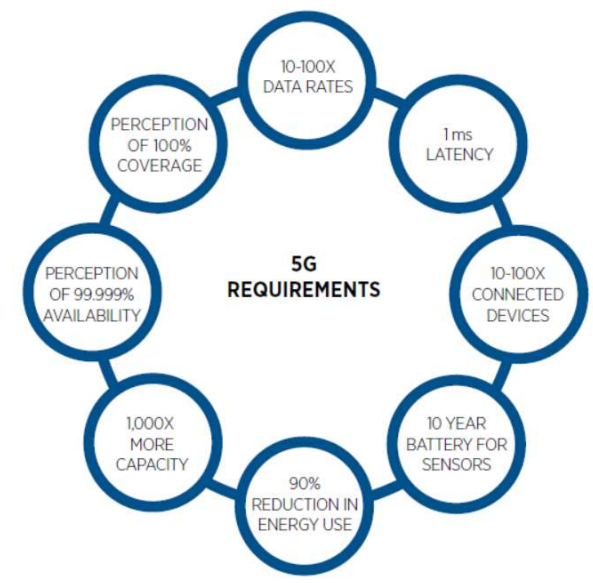

Gambar 2. Parameter layanan dan kinerja Teknologi Seluler 5G.

Teknologi $5 \mathrm{G}$ mendukung penggunaan mm wave yang memungkinkan sinyal dapat dikirimkan pada frekuensi antara $3 \mathrm{GHz}$ hingga $300 \mathrm{GHz}$ (Nugraha \& Hikmaturokhman, 2017). Teknologi $5 \mathrm{G}$ menerapkan penggunaan sejumlah antena pada pengirim dan penerima yang dikenal sebagai MIMO sehingga meningkatkan efisiensi dan kecepatan transmisi. Teknologi seluler 5G memiliki cakupan yang luas dengan menggunakan jaringan heterogen yang mengkombinasikan sejumlah sel-sel mikro dalam suatu sel makro (Admaja, 2015). Arsitektur jaringan teknologi seluler 5G secara umum dapat dilihat pada Gambar 3. Teknologi seluler 5G menyediakan layanan komunikasi Device-to-Device (D2D) yaitu komunikasi langsung antar perangkat; Massive Machine Communications (MMC) untuk mendukung Internet of Things, 
Moving Networks (MN) untuk melayani pengguna yang bergerak; Ultra-Dense Networks(UDN) akan menjadi pendorong utama yang bertujuan untuk meningkatkan kapasitas, meningkatkan efisiensi energi sambungan radio, dan memungkinkan eksploitasi yang lebih baik dari spektrum yang kurang dimanfaatkan; dan melalui UItra Reliable Network (URN) akan memberikan kehandalan jaringan yang tinggi (Gupta \& Jha, 2015).

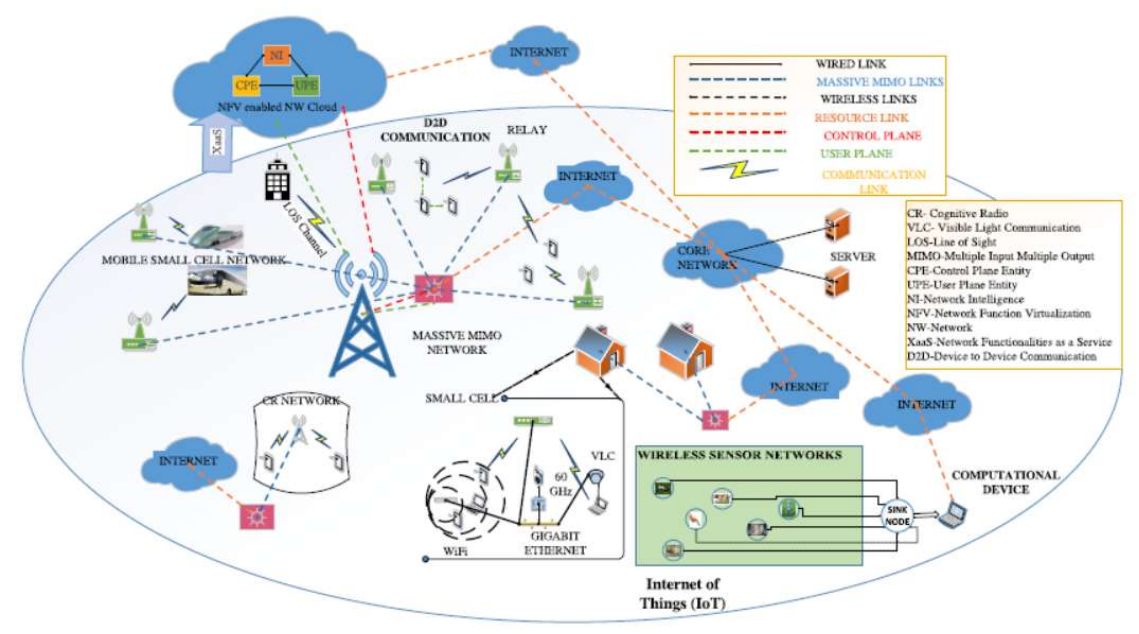

Gambar 3. Arsitektur Jaringan Teknologi Seluler 5G (Gupta \& Jha, 2015)

Terdapat 3 kategori spektrum frekuensi yang diperlukan pada teknologi $5 \mathrm{G}$ agar memberikan jangkauan luas dan dapat mendukung semua use case yang dapat dihadirkan dengan teknologi 5G (Puslitbang SDPPI, 2018). Ketiga spektrum frekuensi yang digunakan pada teknologi seluler $5 \mathrm{G}$ yaitu:

- Low bands, di bawah $1 \mathrm{GHz}$ untuk kebutuhan coverage terutama untuk aplikasi MMTC ( massive IoT dan mobile broadband).

- Mid bands, 1 - $6 \mathrm{GHz}$, bandwidth yang lebih lebar untuk kebutuhan eMBB (enhanced mobile broadband) dan mission-critical.

- High bands, di atas $24 \mathrm{GHz}$ (mmWave) : untuk kebutuhan bandwidth yang sangat besar.

Spektrum frekuensi yang umum untuk teknologi $5 \mathrm{G}$ adalah pada $700 \mathrm{MHz}, 3,5 \mathrm{GHz}$ dan 26/28 $\mathrm{GHz}$. Saat ini di Indonesia spektrum frekuensi $700 \mathrm{MHz}$ masih digunakan untuk layanan broadcast analog. Pita $26 / 28 \mathrm{GHz}$ di Indonesia sedang tidak alokasikan untuk pengguna, sehingga dapat menjadi alternatif terbaik untuk implementasi teknologi 5G. Pita ini menyediakan bandwidth yang lebar hanya saja untuk biaya investasi akan besar cakupan layanan menjadi sempit.

\section{HASIL DAN DISKUSI}

Pada penelitian ini, dilakukan perhitungan path loss yang terjadi antara Base Station (BS) terhadap User Equipment (UE) dengan menerapkan sejumlah parameter sel suatu teknologi seluler 5G untuk wilayah Kota Bandung. Skenario sel yang dipilih sel urban berukuran mikro dengan kombinasi propagasi berupa LOS dan NLOS. Pemilihan kota Bandung sebagai model simulasi perhitungan path loss teknologi 5G, mengingat lokasi yang relatif dekan dengan Ibu Kota Negara dan beberapa operator seluler telah mengadakan pengujian Teknologi 5G menggunakan peralatan pengujian mereka untuk keperluan internal perusahaan. 
Pada penggunaan simulator NYUSIM kondisi iklim dan cuaca memberikan dampak pada hasil perhitungan. Data iklim dan cuaca Kota Bandung serta paremeter teknis dari sistem teknologi seluler $5 \mathrm{G}$ yang digunakan pada perhitungan prediksi nilai path loss diberikan pada Tabel 2.

Tabel 2. Parameter Perhitungan dan Simulasi

\begin{tabular}{|c|c|c|c|}
\hline No & Komponen & Nilai & Keterangan \\
\hline 1 & Frekuensi kerja $(\mathrm{GHz})$ & $\begin{array}{ll}\text { - } & 3,5 \mathrm{GHz}(\mathrm{BW}=100 \mathrm{MHz}) \\
\text { - } & 28 \mathrm{GHz}(\mathrm{BW}=800 \mathrm{MHz})\end{array}$ & \\
\hline 2 & Daya pancar base station & $30 \mathrm{dBm}$ & \\
\hline 3 & Tinggi antena base station & $35 \mathrm{~m}$ & \\
\hline 4 & Tinggi antena user & $1,5 \mathrm{~m}$ & \\
\hline 5 & Tekanan udara & $923,68 \mathrm{mbar}$ & \multirow{4}{*}{$\begin{array}{l}\text { Data cuaca untuk Kota } \\
\text { Bandung (Sumber BMKG), } \\
\text { dipergunakan pada } \\
\text { pemodelan NYUSIM }\end{array}$} \\
\hline 6 & Kelembaban udara & $69 \%$ & \\
\hline 7 & Temperatur & $24^{\circ} \mathrm{C}$ & \\
\hline 8 & Curah hujan & $15 \mathrm{~mm} / \mathrm{jam}$ & \\
\hline
\end{tabular}

Perhitungan nilai path loss antara BS dan posisi UE dilakukan mulai jarak $25 \mathrm{~m}$ hingga jarak $200 \mathrm{~m}$ dengan kelipatan $25 \mathrm{~m}$. Radius sel maksimum pada $200 \mathrm{~m}$ dipilih sebagai salah satu upaya menekan penggunaan daya pancar antena BS dan meningkatkan kapasitas pengguna pada suatu wilayah tertentu. Model prediksi path loss yang digunakan adalah model NYUSIM, model SUI, model ABG dan model CI, masing-masing menggunakan 2 buah frekuensi kerja seperti yang diberikan pada Tabel 2 .

\subsection{Perhitungan Path loss}

Perhitungan path loss mengacu pada ketentuan empat model prediksi yang digunakan dihitung bertahap sesuai dengan skenario perhitungan yang telah disebutkan sebelumnya. Pada pemodelan menggunakan NYUSIM, luaran hasil simulasi prediksi perhitungan lebih lengkap dan beragam informasinya. Kondisi propagasi LOS dan NLOS dapat dikendalikan, dan dapat memberikan hasil untuk penggunaan antena omnidirectional dan antena directional. Melalui hasil yang lebih komprehensif, maka akan dapat melakukan analisis lebih baik.
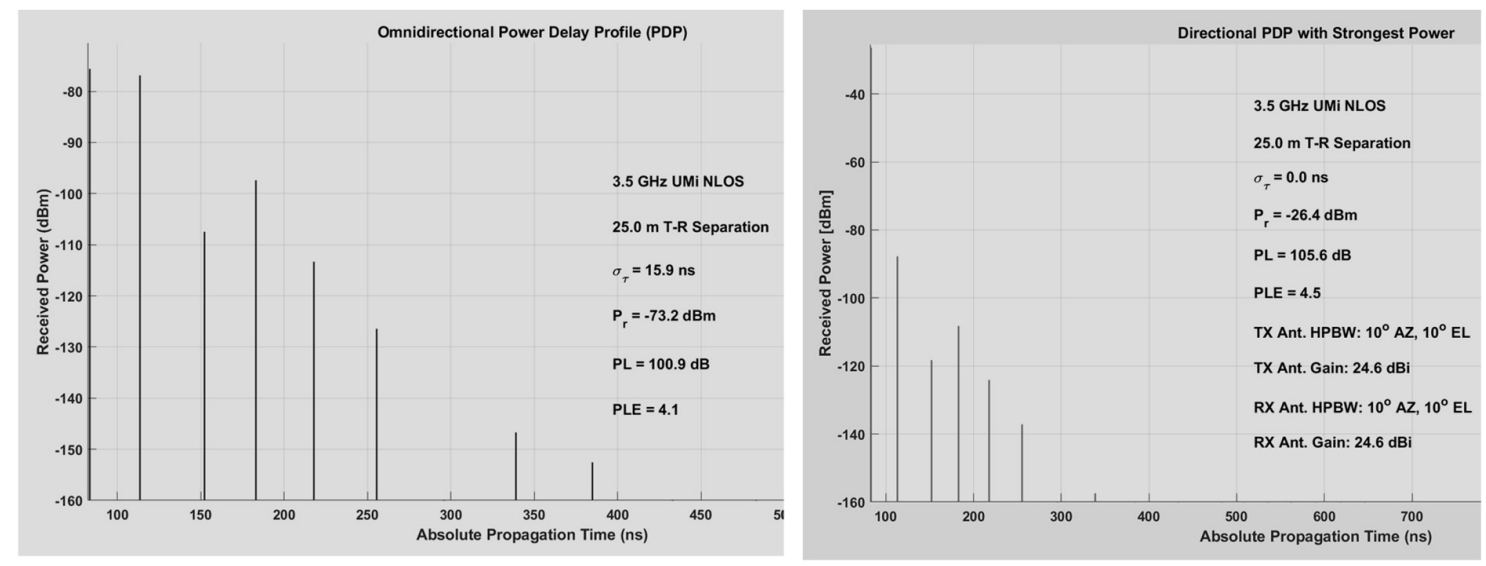

Gambar 4. Power Delay Profile Jarak 25 m pada Frekuensi 3,5 GHz

\subsubsection{Perhitungan Path loss Melalui NYUSIM}

Melalui pemodelan NYUSIM menggunakan parameter-parameter pada Tabel 2, diperoleh hasil simulasi seperti yang ditampilkan pada Gambar 4 untuk frekuensi 3,5 MHz pada jarak 25 meter dan Gambar 5 untuk frekuensi $28 \mathrm{GHz}$ pada jarak 200 meter. Pada setiap hasil simulasi yang ditampilkan seperti pada contoh Gambar 4 dan Gambar 5 keluaran simulator NYUSIM 
menampilkan nilai Path Loss (PL) antara BS dan UE pada jarak tertentu untuk kondisi NLOS. Pada hasil simulasi NYUSIM juga menampilkan profile path delay yang mencerminkan karakteristik multipath sinyal yang diterima pada UE. Setelah melakukan perhitungan untuk keseluruhan variasi jarak BS ke UE dan penggunaan 2 frekuensi kerja yaitu 3,5 GHz dan 28 $\mathrm{GHz}$, maka diperoleh hasil keseluruhan nilai path loss seperti pada Tabel 3 dan Tabel 4.
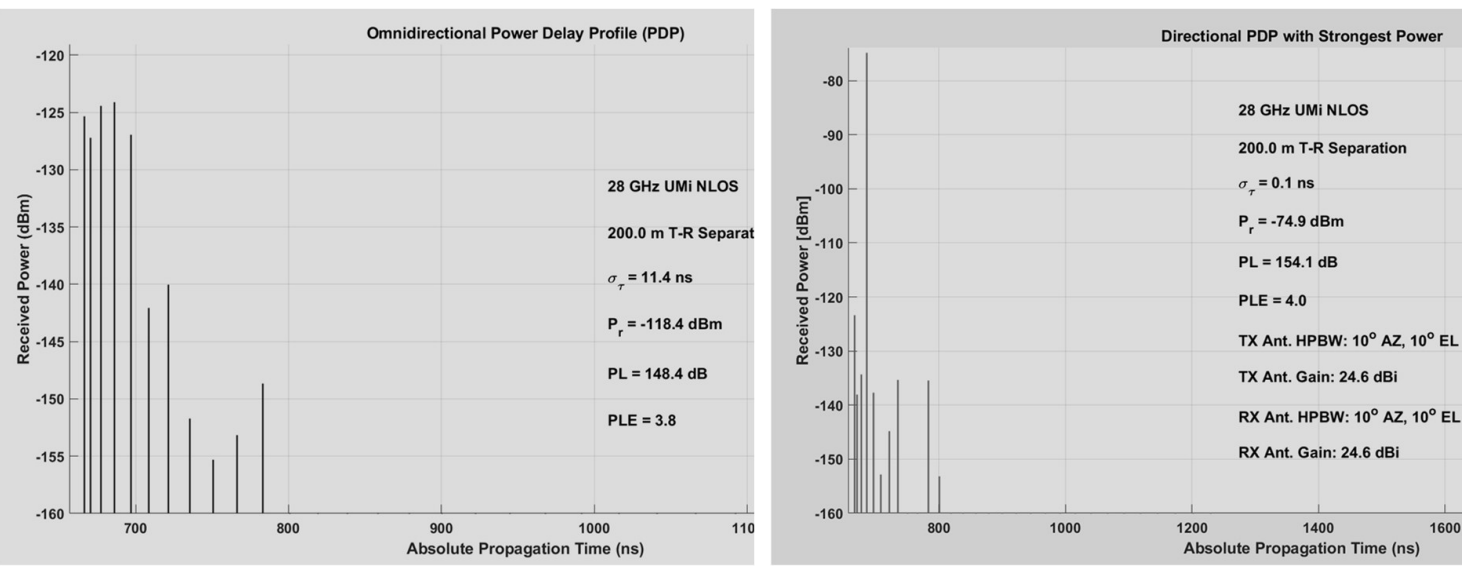

Gambar 5. Power Delay Profile Jarak 200 m Pada Frekuensi 28 GHz

Tabel 3. Nilai Path loss Hasil Simulasi NYUSIM (Frekuensi 3,5 GHz)

\begin{tabular}{|c|c|c|c|c|}
\hline \multirow{2}{*}{$\begin{array}{c}\text { Jarak BS-UE } \\
(\mathbf{m})\end{array}$} & \multicolumn{4}{|c|}{ Path loss (dB) } \\
\cline { 2 - 5 } & \multicolumn{2}{|c|}{ Omnidirectional } & \multicolumn{2}{c|}{ Directional } \\
\cline { 2 - 5 } & LOS & NLOS & LOS & NLOS \\
\hline 25 & 78,6 & 100,9 & 78,2 & 105,6 \\
\hline 50 & 84,6 & 110,5 & 84,2 & 115,3 \\
\hline 75 & 88,2 & 116,2 & 87,4 & 120,9 \\
\hline 100 & 90,7 & 120,2 & 90,3 & 124,9 \\
\hline 125 & 92,6 & 123,3 & 92,2 & 128,0 \\
\hline 150 & 94,2 & 125,8 & 93,8 & 130,5 \\
\hline 175 & 95,5 & 127,9 & 95,1 & 132,7 \\
\hline 200 & 96,7 & 129,8 & 96,3 & 134,5 \\
\hline
\end{tabular}

Tabel 4. Nilai Path loss Hasil Simulasi NYUSIM (Frekuensi 28 GHz)

\begin{tabular}{|c|c|c|c|c|}
\hline \multirow{2}{*}{$\begin{array}{c}\text { Jarak BS-UE } \\
(\mathbf{m})\end{array}$} & \multicolumn{4}{|c|}{ Path loss (dB) } \\
\cline { 2 - 5 } & \multicolumn{2}{|c|}{ Omnidirectional } & \multicolumn{2}{c|}{ Directional } \\
\cline { 2 - 5 } & LOS & NLOS & LOS & NLOS \\
\hline 25 & 96,7 & 119,0 & 103,3 & 124,8 \\
\hline 50 & 102,8 & 128,7 & 109,4 & 134,4 \\
\hline 75 & 106,4 & 134,4 & 113,0 & 140,1 \\
\hline 100 & 109,0 & 138,5 & 115,6 & 144,2 \\
\hline 125 & 111,0 & 141,6 & 117,6 & 147,4 \\
\hline 150 & 112,6 & 144,2 & 119,2 & 150,0 \\
\hline 175 & 114,0 & 146,4 & 120,6 & 152,2 \\
\hline 200 & 115,3 & 148,4 & 121,9 & 154,1 \\
\hline
\end{tabular}




\subsubsection{Perhitungan Path loss Model Prediksi SUI, ABG dan CI}

Model prediksi SUI, ABG dan CI digunakan untuk melakukan estimasi nilai path loss khususnya pada kondisi NLOS. Untuk perhitungan nilai path loss menggunakan model SUI dilakukan menggunakan Persamaan (1), dimana konstanta yang digunakan mengacu pada terain type A. Pada terain type A digunakan nilai-nilai konstanta sebagai berikut: nilai $a=4,6, b=0,0075$, $\mathrm{c}=12,6$, nilai mean $=0$ dan standar deviasi $=8$.

Perhitungan nilai path loss menggunakan model ABG dan CI mengacu pada Persamaan (2) dan (3), dimana konstanta parameter $\alpha, \beta, \gamma$, dan $\sigma$ yang digunakan menggunakan nilai-nilai pada Tabel 1. Untuk model ABG, menggunakan nilai konstanta $\alpha=3,5, \beta=24,4, \gamma=1,9$, dan $\sigma=8$. Sedangkan untuk model CI menggunakan nilai konstanta $\alpha=3,1$ dan $\sigma=8,1$.

Perhitungan nilai prediksi path loss untuk ketiga model prediksi UI, ABG dan CI ditampilkan pada Tabel 5 untuk frekuensi kerja 3,5 GHz dan $28 \mathrm{GHz}$.

Tabel 5. Hasil Path loss Berdasarkan Model SUI, ABG dan CI

\begin{tabular}{|c|c|c|c|c|c|c|}
\hline \multirow{2}{*}{$\begin{array}{c}\text { Jarak BS-UE } \\
(\mathbf{m})\end{array}$} & \multicolumn{7}{|c|}{ Prekuensi 3,5 GHz } & \multicolumn{3}{c|}{ Frekuensi 28 GHz } \\
\cline { 2 - 7 } & SUI & ABG & CI & SUI & ABG & CI \\
\cline { 2 - 7 } & 119,79 & 103,65 & 80,30 & 143,27 & 120,81 & 98,37 \\
\hline 25 & 133,94 & 116,89 & 88,73 & 157,42 & 134,05 & 106,79 \\
\hline 50 & 142,21 & 124,64 & 93,66 & 165,69 & 141,80 & 111,72 \\
\hline 75 & 148,08 & 130,14 & 97,16 & 171,56 & 147,30 & 115,22 \\
\hline 100 & 152,63 & 134,40 & 99,87 & 176,11 & 151,56 & 117,94 \\
\hline 125 & 156,35 & 137,89 & 102,09 & 179,83 & 155,04 & 120,15 \\
\hline 150 & 159,49 & 140,83 & 103,97 & 182,97 & 157,99 & 122,03 \\
\hline 175 & 162,22 & 143,38 & 105,59 & 185,70 & 160,54 & 123,65 \\
\hline 200 & & & & & & \\
\hline
\end{tabular}

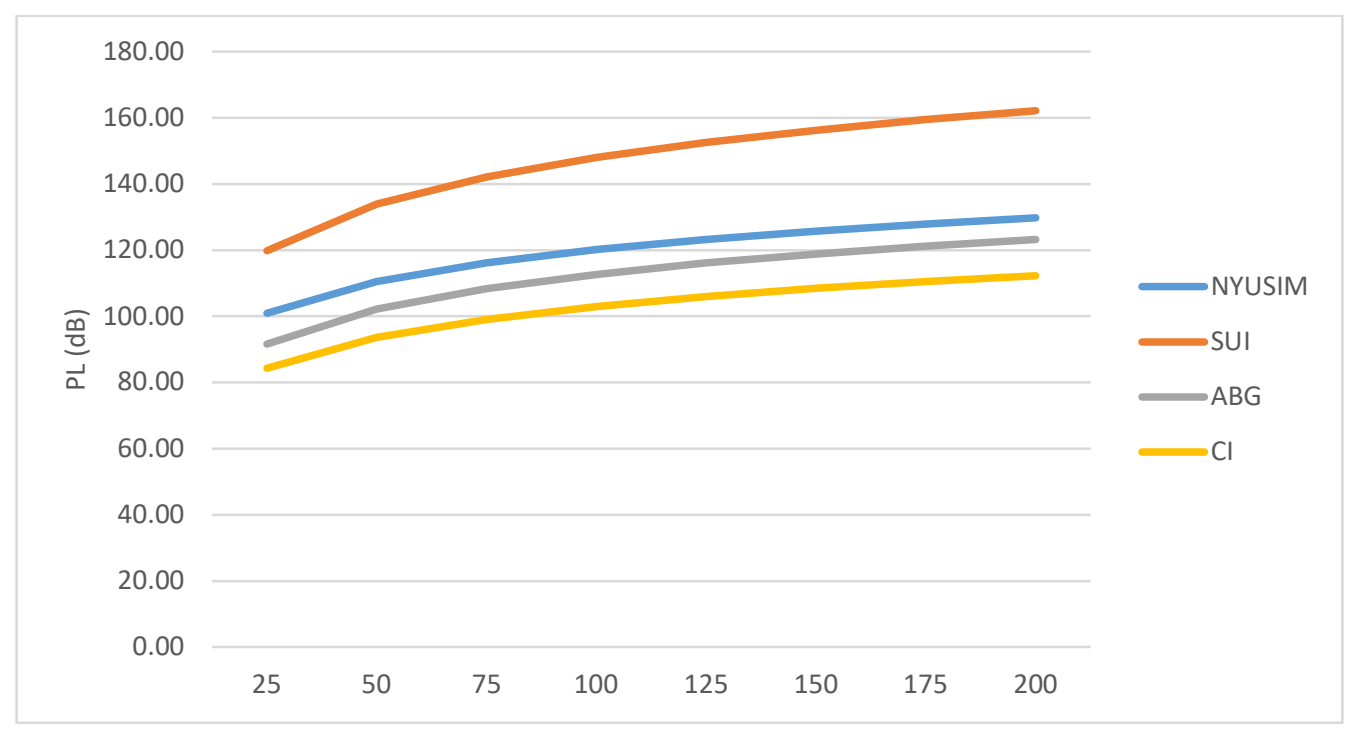

Gambar 6. Profil Nilai Path loss Setiap Model Prediksi pada Frekuensi 3,5 GHz 
Gambar 6 dan Gambar 7 menampilkan secara visual perbedaan hasil perhitungan nilai prediksi path loss dari setiap model prediksi. Melalui Gambar 6 dan Gambar 7 dapat dilihat nilai prediksi path loss sebagai dari fungsi terhadap jarak untuk semua model yang digunakan pada frekuensi kerja 3,5 GHz dan $28 \mathrm{GHz}$, dimana semakin besar jarak, maka nilai path loss akan semakin membesar. Masing-masing model prediksi memiliki kecenderungan yang hampir serupa, hanya saja terlihat bahwa model SUI memiliki hasil perhitungan path loss yang paling besar nilainya dibandingkan dengan ketiga model prediksi lainnya. Model prediksi CI memiliki hasil perhitungan prediksi path loss yang paling rendah. Penggunaan frekuensi yang tinggi berdampak pada meningkatnya nilai path loss juga terlihat pada seluruh model prediksi.

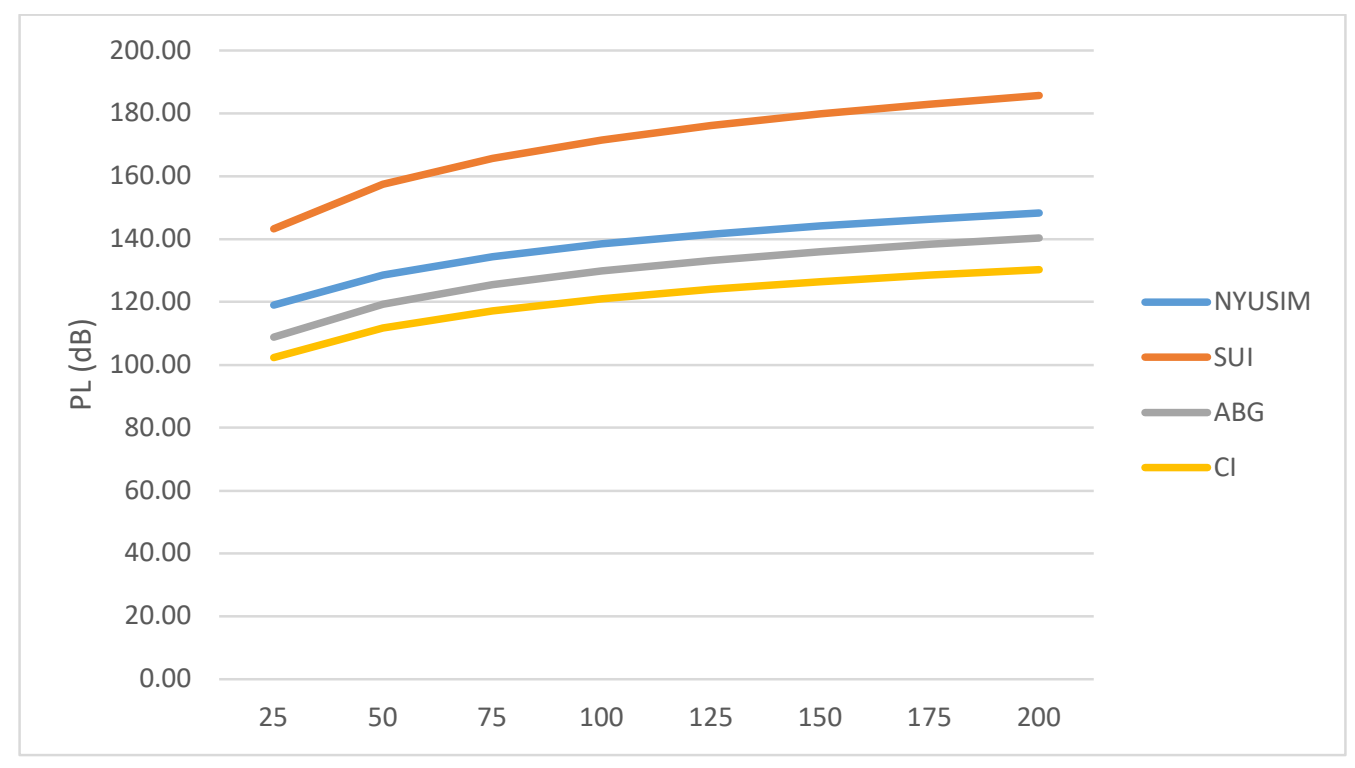

\section{Gambar 7. Profil Nilai Path loss Setiap Model Prediksi pada Frekuensi 28 GHz}

Untuk mendapatkan nilai optimal dari keempat model prediksi path loss langkah berikutnya adalah menghitung nilai rata-rata path loss untuk masing-masing jarak, sehingga diperoleh nilai path loss seperti pada Tabel 6.

Tabel 6. Rata-rata Nilai Path loss Sel Mikro Urban NLOS

\begin{tabular}{|c|c|c|}
\hline \multirow{2}{*}{$\begin{array}{c}\text { Jarak BS-UE } \\
(\mathbf{m})\end{array}$} & \multicolumn{2}{|c|}{ Rata-Rata PL (dB) } \\
\cline { 2 - 3 } & $\mathbf{F = 3 , 5 ~ G H z}$ & $\mathbf{F = 2 8} \mathbf{~ G H z}$ \\
\hline 25 & 99,16 & 118,36 \\
\hline 50 & 110,07 & 129,29 \\
\hline 75 & 116,46 & 135,69 \\
\hline 100 & 120,99 & 140,24 \\
\hline 125 & 124,51 & 143,76 \\
\hline 150 & 127,37 & 146,64 \\
\hline 175 & 129,78 & 149,08 \\
\hline 200 & 131,90 & 151,22 \\
\hline
\end{tabular}

Berdasarkan nilai rata-rata pada Tabel 6, maka dapat disimpulkan bahwa hasil perhitungan path loss yang paling mendekati adalah hasil path loss hasil simulasi menggunakan NYUSIM. Kesimpulan ini diperoleh setelah menghitung nilai selisih hasil antara nilai rata-rata path loss pada Tabel 6 dengan masing-masing hasil path loss dari setiap model prediksi yang digunakan. 
Analisis Prediksi Path Loss Teknologi Seluler 5G Pada Sel Micro Urban Wilayah Kota Bandung

Tabel 7. Selisih Nilai Path loss Model Prediksi terhadap Nilai Rata-rata Path Loss

\begin{tabular}{|c|c|c|c|c|c|c|c|c|}
\hline \multirow{3}{*}{$\begin{array}{l}\text { Jarak } \\
\text { BS-UE }\end{array}$} & \multicolumn{8}{|c|}{ Selisih Terhadap Nilai Rata-rata Path Loss } \\
\hline & \multicolumn{2}{|c|}{$\begin{array}{c}\text { Model } \\
\text { NYUSIM }\end{array}$} & \multicolumn{2}{|c|}{ Model SUI } & \multicolumn{2}{|c|}{ Model ABG } & \multicolumn{2}{|c|}{ Model CI } \\
\hline & $\begin{array}{c}\mathrm{F}=3,5 \\
\mathrm{GHz}\end{array}$ & $\begin{array}{l}F=28 \\
G H z\end{array}$ & $\begin{array}{c}\mathrm{F}=3,5 \\
\mathrm{GHz}\end{array}$ & $\begin{array}{c}\mathrm{F}=28 \\
\mathrm{GHz}\end{array}$ & $\begin{array}{c}\mathrm{F}=3,5 \\
\mathrm{GHz}\end{array}$ & $\begin{array}{c}\mathrm{F}=28 \\
\mathrm{GHz}\end{array}$ & $\begin{array}{c}\mathrm{F}=3,5 \\
\mathrm{GHz}\end{array}$ & $\begin{array}{c}\mathrm{F}=28 \\
\mathrm{GHz}\end{array}$ \\
\hline 25 & 1,74 & 0,64 & 20,63 & 24,91 & 7,50 & 24,91 & 14,87 & 16,01 \\
\hline 50 & 0,43 & 0,59 & 23,87 & 28,12 & 7,87 & 28,12 & 16,44 & 17,60 \\
\hline 75 & 0,26 & 1,29 & 25,74 & 30,00 & 8,10 & 30,00 & 17,38 & 18,54 \\
\hline 100 & 0,79 & 1,74 & 27,08 & 31,31 & 8,26 & 31,31 & 18,03 & 19,22 \\
\hline 125 & 1,21 & 2,16 & 28,12 & 32,35 & 8,38 & 32,35 & 18,54 & 19,73 \\
\hline 150 & 1,57 & 2,44 & 28,98 & 33,19 & 8,47 & 33,19 & 18,95 & 20,16 \\
\hline 175 & 1,88 & 2,68 & 29,71 & 33,89 & 8,54 & 33,89 & 19,29 & 20,53 \\
\hline 200 & 2,10 & 2,82 & 30,32 & 34,48 & 8,62 & 34,48 & 19,60 & 20,87 \\
\hline $\begin{array}{l}\text { Rata-rata } \\
\text { Selisih }\end{array}$ & 1,25 & 1,80 & 26,81 & 31,03 & 8,22 & 31,03 & 17,89 & 19,08 \\
\hline
\end{tabular}

Selisih terkecil path loss rata-rata terhadap nilai path loss hasil simulasi NYUSIM adalah sebesar $1,25 \mathrm{~dB}$ untuk frekuensi $3,5 \mathrm{GHz}$ dan $1,8 \mathrm{~dB}$ untuk frekuensi $28 \mathrm{GHz}$. Model prediksi SUI memiliki selisih hasil terbesar terhadap hasil rata-rata path loss yaitu sebesar 26,81 dB untuk frekuensi 3,5 GHz dan 31,03 dB untuk frekuensi $28 \mathrm{GHz}$.

Model NYUSIM memiliki kelebihan dibandingkan dengan model lainnya, dimana dapat menghitung nilai path loss pada kondisi LOS maupun NLOS. Kondisi LOS secara teoritis memiliki kinerja lebih baik dibandingkan NLOS. Bardasarkan data pada Tabel 3 dan Tabel 4, dapat disimpulkan kondisi LOS terhadap NLOS terdapat selisih nilai path loss sebesar 35\% pada frekuensi $3,5 \mathrm{GHz}$ dan $26 \%$ pada frekuensi $28 \mathrm{GHz}$.

\section{KESIMPULAN}

Penggunaan sejumlah model prediksi untuk menghitung nilai path loss yang terjadi antara base station dan user equipment memberikan hasil yang bervariasi. Keseluruhan model prediksi memiliki kecenderungan nilai path loss bergantung pada jarak dan besar frekuensi yang digunakan. Nilai path loss terbesar diperoleh pada saat menggunakan model prediksi SUI dan nilai terendah pada penggunaan model prediksi CI untuk jarak BS-UE pada rentang 25 hingga 200 meter. Penggunaan model prediksi NYUSIM menghasilkan nilai prediksi path loss yang paling mendekati nilai rata-rata path loss dengan nilai margin sebesar $1,25 \mathrm{~dB}$ untuk frekuensi 3,5 GHz dan 1,8 dB untuk frekuensi $28 \mathrm{GHz}$. Frekuensi kerja $28 \mathrm{GHz}$ menghasilkan nilai path loss yang lebih tinggi sebesar $19 \mathrm{~dB}$ dibandingkan dengan penggunaan frekuensi kerja 3,5 GHz. Melalui model NYUSIM dapat dihitung selisih nilai path loss pada kondisi LOS dan NLOS sebesar 35\% pada frekuensi $3,5 \mathrm{GHz}$ dan $26 \%$ pada frekuensi $28 \mathrm{GHz}$. 


\section{DAFTAR RUJUKAN}

Sulyman, A. I., Nassar A. T., Samimi M. K., Maccartney G. R., Rappaport T. S. and Alsanie, A.. (2014). Radio propagation path loss models for $5 \mathrm{G}$ cellular networks in the $28 \mathrm{GHz}$ and $38 \mathrm{GHz}$ millimeter-wave bands. IEEE Communications Magazine, 52(9), 78-86. https://doi.org/10.1109/MCOM.2014.6894456.

Gupta, A. and Jha, R. K.. (2015). A Survey of 5 G Network: Architecture and Emerging Technologies. IEEE Access, (pp. 1206-1232).

5 G Americas. (2017). 5G Spectrum Recommendations. Retrieved from http://www.5gamericas.org/files/9114/9324/1786/5GA_5G_Spectrum_Recommendati ons_2017_FINAL.pdf.

Ofcom. (2017). Update on 5G spectrum in the UK. Retrieved from https://www.ofcom.org.uk/_data/assets/pdf_file/0021/97023/5G-update08022017.pdf

Puslitbang SDPPI. (2018). Studi Lanjutan 5G Indonesia 2018 Spektrum Outlook dan Use Case untuk Layanan 5G Indonesia. Puslitbang Sumber Daya, Perangkat, dan Penyelenggaraan Pos dan Informatika, Badan Penelitian dan Pengembangan SDM, Kementerian Komunikasi dan Informatika.

Rappaport, T. S., dkk. (2013). Millimeter Wave Mobile Communications for 5 G Cellular: It Will Work!. IEEE Access, (pp. 335-349). https://doi.org/10.1109/ACCESS.2013.2260813.

Sun, S., dkk. (2016). Propagation Path loss Models for 5G Urban Micro- and Macro-Cellular Scenarios. IEEE 83 $3^{\text {rd }}$ Vehicular Technology Conference (VTC Spring), (pp. 1-6).

Sun, S., MacCartney Jr., G. R., and Rappaport, T. S.. (2017). A novel millimeter-wave channel simulator and applications for $5 \mathrm{G}$ wireless communications. IEEE International Conference on Communications (ICC), (pp. 1-7). https://doi.org/10.1109/ICC.2017.7996792.

Ju, S., Kanhere, O., Xing, Y. and Rappaport, T. S.. (2019). A Millimeter-Wave Channel Simulator NYUSIM with Spatial Consistency and Human Blockage. IEEE Global Communications Conference (GLOBECOM), (pp. 1-6).

Rappaport, T. S., Sun, S., and Shafi, M.. (2017). Investigation and comparison of 3GPP and NYUSIM channel models for $5 \mathrm{G}$ wireless communications. IEEE 86th Vehicular Technology Conference (VTC Fal), (pp. 1-5).

Admaja, A. F. S. (2015). Kajian Awal 5G Indonesia. Buletin Pos dan Telekomunikasi, 13(2), 97-114. http://dx.doi.org/10.17933/bpostel.2015.130201.

Thomas, T. A., dkk. (2016). A Prediction Study of Path Loss Models from 2-73.5 GHz in an ELKOMIKA - 560 
Urban-Macro Environment. IEEE 83rd Vehicular Technology Conference (VTC Spring), (pp. 1-5).

Ju, S., dkk. (2020). NYUSIM User Manual. New York University and NYU WIRELESS.

Obiodu, E. (2019). THE 5G GUIDE A REFERENCE FOR OPERATORS. Retrieved from https://www.gsma.com/wp-content/uploads/2019/04/The-5G-

Guide_GSMA_2019_04_29_compressed.pdf.

Nugraha, T.A., Hikmaturokhman, A.. (2017). Simulasi Penggunaan Frekuensi Milimeter Wave Untuk Akses Komunikasi Jaringn 5G Indoor. Jurnal INFOTEL, 9(1), 24-30. https://doi.org/10.20895/infotel.v9i1.144

Haneda, K., dkk. (2016). 5G 3GPP-Like Channel Models for Outdoor Urban Microcellular and Macrocellular Environments. IEEE 83rd Vehicular Technology Conference (VTC Spring), (pp. 1-7). https://doi.org/10.1109/VTCSpring.2016.750397 